\title{
Synthesis and Stereochemistry of Some New 1,3-Dioxane Derivatives of 1,4-Benzenedicarbaldehyde
}

\author{
Ion Grosu, ${ }^{a, *}$ Sorin Mager, ${ }^{a}$ Loïc Toupet, ${ }^{b}$ Gerard Plé, $^{c}$ Eugen Mesaros ${ }^{a}$ and Alin Mihis ${ }^{a}$ \\ a'Babes-Bolyai' University, Organic Chemistry Department, 11 Arany Janos str., RO-3400 Cluj-Napoca, România, \\ 'Université de Rennes I, UMR C6626, 35042 Rennes, Cedex, France and 'Université de Rouen et IRCOF, \\ UPRES-A-6014, Faculté des Sciences de Rouen, 76821 Mont Saint Aignan, Cedex, France
}

\begin{abstract}
Grosu, I., Mager, S., Toupet, L., Plé, G., Mesaros, E. and Mihis, A., 1998. Synthesis and Stereochemistry of Some New 1,3-Dioxane Derivatives of 1,4-Benzenedicarbaldehyde. - Acta Chem. Scand. 52: 366-371. (C) Acta Chemica Scandinavica 1998.

The stereochemistry of some new 1,3-dioxanes prepared from 1,4-benzenedicarbaldehyde has been deduced from NMR studies and from the crystal structure of one compound determined by single-crystal X-ray diffractometry. trans, trans; cis, cis and cis, trans isomers of some of these compounds have been identified and their ratio has been calculated from NMR spectra.
\end{abstract}

Studies $^{1-4}$ on the stereochemistry of some 2-aryl1,3-dioxane derivatives have showed high $A$-values of the aromatic group located in position 2 of the heterocycle (e.g. $\Delta G_{\mathrm{Ph}}^{\circ}=3.12 \mathrm{kcal} \mathrm{mol}^{-1}$ ). ${ }^{1}$ These studies have revealed the possibility of using these substituents as efficient 'holding groups'. The characteristic conformational equilibria (Scheme 1) are shifted towards conformation $\left(C_{1}\right)$ showing the aryl group to occupy the equatorial position. In solutions (at room temperature) the equatorial aromatic substituent exhibits free rotation around its bond to the heterocycle, while in the solid state packing forces may determine the preference of the aryl group for a bisectional or orthogonal rotamer. ${ }^{5-7}$<smiles>[R]C1([R])COC([3H])([3H])OC1</smiles><smiles>[R]C1([R])COC([Al])([Al]C)OC1</smiles>

Scheme 1.

Recent studies 8,9 have showed the cis and trans stereoisomerism of some 1,3-dioxane derivatives of 1,2-benzenedicarbaldehyde bearing only one substituent in position $5\left(5^{\prime}\right)$ of the heterocycle. The aromatic group assumes equatorial orientations with respect to both dioxanes, whereas the substituents located in position $5\left(5^{\prime}\right)$ of the two 1,3-dioxane rings show an axial or equatorial orientation generating cis, cis; trans, trans and cis, trans isomers.

In the present study the stereochemistry of some new 1,3-dioxane acetals of 1,4-benzenedicarbaldehyde (tere-

\footnotetext{
* To whom correspondence should be addressed.
}

phthaldialdehyde) has been investigated and the conformational behaviour of these compounds has been compared with the data reported for other 2-aryl-1,3dioxane derivatives. ${ }^{8-11}$

\section{Results and discussion}

The new 1,3-dioxane derivatives were obtained by acetalization of 1,4-benzenedicarbaldehyde with several substituted 1,3-propanediols (Scheme 2).

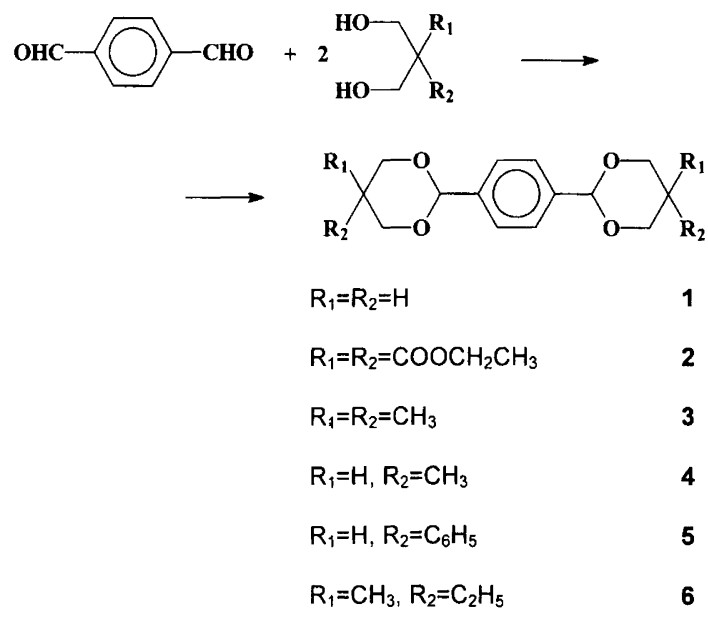

Scheme 2.

Compounds 1-3 are single diastereoisomers whereas compounds 4-6 may exhibit many configurational isomers.

Compounds 1-3 show anancomeric structures, i.e., the conformational equilibrium associated with the flipping 


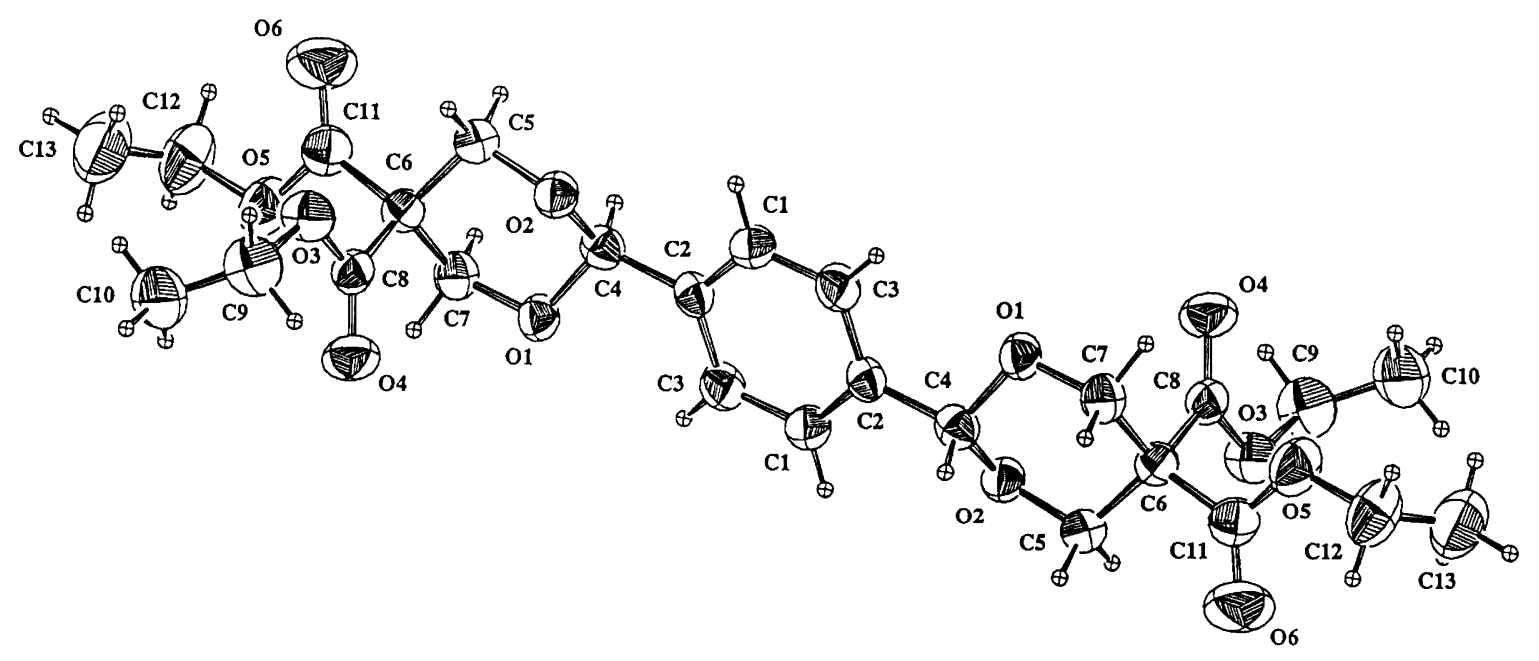

Fig. 1. ORTEP diagram of compound 2.

Table 1. Structural parameters of compound $\mathbf{2}$ determined by single-crystal X-ray diffractometry.

\begin{tabular}{llllll}
\hline Bond & Length $/ \AA$ & Bong angle & $\begin{array}{l}\text { Values of } \\
\text { bond angles }{ }^{\circ}\end{array}$ & Torsion angle & $\begin{array}{c}\text { Values of } \\
\text { torsion angles } /^{\circ}\end{array}$ \\
\hline$C^{4}-O^{1}$ & $1.409(3)$ & $C^{4}-O^{1}-C^{7}$ & $111.6(2)$ & $C^{7} O^{1} C^{4} O^{2}$ & $-63.15(0.30)$ \\
$O^{1}-C^{7}$ & $1.420(3)$ & $C^{4}-O^{2}-C^{5}$ & $110.2(2)$ & $C^{4} O^{1} C^{7} C^{6}$ & $56.27(0.31)$ \\
$C^{6}-C^{7}$ & $1.529(5)$ & $C^{5}-C^{6}-C^{7}$ & $108.3(2)$ & $C^{5} O^{2} C^{4} O^{1}$ & $64.63(0.29)$ \\
$C^{5}-C^{6}$ & $1.531(4)$ & $O^{1}-C^{7}-C^{6}$ & $111.2(2)$ & $O^{2} C^{5} C^{6} C^{7}$ & $51.47(0.33)$ \\
$C^{5}-O^{2}$ & $1.425(3)$ & $O^{1}-C^{4}-O^{2}$ & $110.3(2)$ & $C^{4} O^{2} C^{5} C^{6}$ & $-59.49(0.30)$ \\
$O^{2}-C^{4}$ & $1.412(4)$ & $O^{2}-C^{5}-C^{6}$ & $110.5(2)$ & $C^{5} C^{6} C^{7} O^{1}$ & $-49.72(0.33)$ \\
\hline
\end{tabular}

of the heterocycles can be shifted towards the conformation with equatorial phenylene groups. The aromatic substituent can be considered as a 'holding group' for both 1,3-dioxane rings. This conformational behaviour of the compounds has been deduced from the molecular structure of compound $\mathbf{2}$ as determined by single-crystal $\mathrm{X}$-ray diffractometry and by the NMR investigations of these compounds.

The ORTEP diagram of compound 2 (Fig. 1) shows the equatorial orientation of the 1,4-phenylene group for both heterocycles and a preference of the aromatic group for an arrangement close to the ideal orthogonal rotamer. The small deviation from the ideal orthogonal orientation of the best planes of the 1,3-dioxane rings $\left(P_{1}\right.$ : $\left.\mathrm{C}^{4} \mathrm{C}^{6} \mathrm{C}^{8} \mathrm{C}^{11} ; P_{2}: \mathrm{C}^{4 a} \mathrm{C}^{6 a} \mathrm{C}^{8 \mathrm{a}} \mathrm{C}^{11 \mathrm{a}}\right)$ and the plane of the aromatic ring $\left(P: \mathrm{C}^{1-3} \mathrm{C}^{1 \mathrm{a}-3 \mathrm{a}}\right)$ has been calculated $\left(P / P_{1}=\right.$ $\left.99.3^{\circ} ; P_{1} / P_{2}=0^{\circ}\right)$. From the structural parameters $\dagger$ (Table 1 ) it could be obsereved that the structure of the heterocycles were close to the ideal chair conformation. The two 1,3-dioxane rings assume, in the solid-state, an 'anti' orientation caused by the dispositions of the axial protons in positions 2 and 2 ', which are located on the opposite faces of the aromatic ring considered, in this case, as the best plane.

The NMR spectra of the compounds (Table 2) show different signals for the axial and equatorial protons in

\footnotetext{
$\dagger$ The X-ray crystallographic material has been deposited with the Cambridge Crystallographic Data Centre.
}

positions $4\left(4^{\prime}\right)$ and $6\left(6^{\prime}\right)$ as well as for the protons and the carbon atoms of similar groups located in positions 5 and $5^{\prime}$ (compounds 2 and 3 ).

The ${ }^{1} \mathrm{H}$ NMR spectrum of compound 2 (Fig. 2, Table 2) shows unique signals for the protons of the two heterocycles. The axial protons in positions 2 and $2^{\prime}$ give rise to a singlet $(\delta 5.18)$ and the equatorial protons in positions $4\left(4^{\prime}\right)$ and $6\left(6^{\prime}\right)$ show a deshielded doublet $\left[\delta_{4\left(4^{\prime}\right), 6\left(6^{\prime}\right) \text { eq }} 5.04\right]$ while for the axial protons a different doublet $\left[\delta_{4\left(4^{\prime}\right), 6\left(6^{\prime}\right) \text { ax }} 3.95\right]$ has been observed. The difference in the chemical shifts between the signals belonging to the protons of the axial and the equatorial ester groups is in the usual range $\mathrm{e}^{10-12}$ observed for anancomeric 1,3-dioxane derivatives exhibiting axial and equatorial ethyloxycarbonyl groups in position 5 of the 1,3-dioxane ring [e.g., for the methylene protons the spectrum shows two quartets (Fig. 2): $\delta_{\mathrm{ax}} 4.01, \delta_{\mathrm{eq}} 3.77$ and $\left.\Delta \delta_{\mathrm{ax}-\mathrm{q}} 0.24\right]$.

Careful inspection of the ${ }^{1} \mathrm{H}$ NMR spectra of compounds 2 and 3 recorded at room temperature revealed complex signals for the protons in positions $4\left(4^{\prime}\right)$ and $6\left(6^{\prime}\right)$. Instead of the simple AX system, the pattern of an $\mathrm{AA}^{\prime} \mathrm{XX}^{\prime}$ spin system was observed. The complex structure of the signals is due to the long-range couplings involving the protons of the heterocycle. The values of the coupling constants in 2 were calculated from the simulated spectrum $\left(J_{4 \mathrm{e}, 6 \mathrm{e}}=-1.7, J_{4(6) \mathrm{a}, 6(4) \mathrm{e}}=-0.47\right.$ and $\left.J_{4(6) \mathrm{a}, 4(6) \mathrm{e}}=-10.9 \mathrm{~Hz}\right)$ and are similar to data reported for other anancomeric 1,3-dioxane compounds. ${ }^{1,8}$ 
Table 2. Significant NMR data $(\delta)$ for compounds 1-6.

\begin{tabular}{lllll}
\hline & & \multicolumn{2}{l}{ Positions $4\left(4^{\prime}\right), 6\left(6^{\prime}\right)$} & \\
\cline { 3 - 5 } Compound & Positions 2(2') & Equatorial & Axial & $\Delta$ \\
\hline $\mathbf{1}$ & 5.30 & 3.87 & 3.43 & 0.44 \\
$\mathbf{2}$ & 5.18 & 5.04 & 3.95 & 1.09 \\
$\mathbf{3}$ & 5.25 & 3.52 & 3.25 & 0.27 \\
$\mathbf{4}$ (diastereoisomer I) & 5.27 & 3.89 & 3.08 & 0.81 \\
$\mathbf{6}$ (diastereoisomer I) & 5.41 & 4.15 & 3.68 & 0.47 \\
$\mathbf{6}$ (cycles B) & $(5.259,5.268$ & $3.610,3.614$ & 3.280 & 0.33 \\
\hline
\end{tabular}
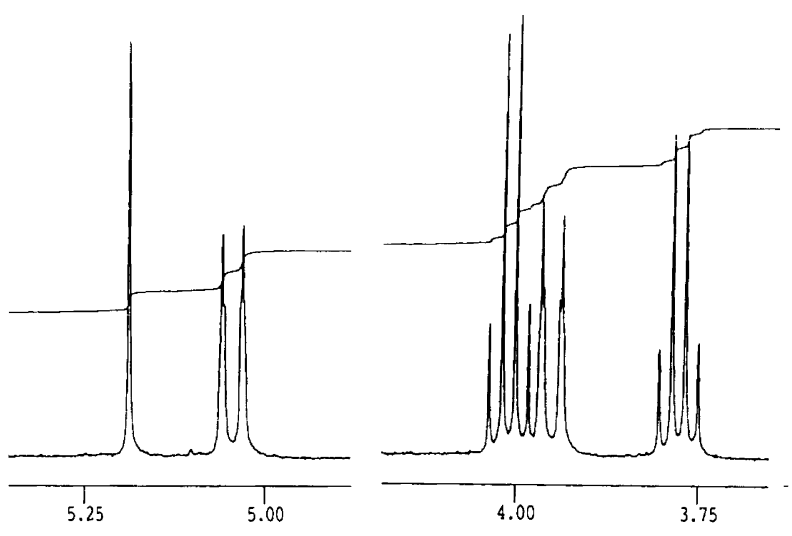

Fig. 2. ${ }^{1} \mathrm{H}$ NMR spectrum (fragment) of compound 2.

Compounds 4-6 also display anancomeric structures showing the equatorial position of the 1,4-phenylene group in both heterocycles. The substituents in positions 5 and $5^{\prime}$, however, can take up equatorial or axial positions, generating three diastereoisomers [Scheme 3, trans or cis dispositions of the substituents in position $5\left(5^{\prime}\right)$ and of the aromatic ring in position $\left.2\left(2^{\prime}\right)\right]$.

The diastereoisomer in which the reference groups in position $5\left(5^{\prime}\right)$ (Me for compound $4, \mathrm{Ph}$ for compound 5 , Et in the case of compound 6) and the aromatic substituent in position $2\left(2^{\prime}\right)$ are trans with respect to both 1,3-dioxane rings is denoted with $\mathbf{I}$. The diastereoisomer displaying the above-mentioned groups $c i s$ with respect to both heterocycles is denoted II, whereas the diastereoisomer showing a cis configuration for the substituents belonging to one of the 1,3-dioxane rings and a trans configuration for the substituents on the second dioxane ring is denoted III.

The synthesis of compounds $\mathbf{4}$ and $\mathbf{5}$ leads to a mixture of diastereoisomers, I and III. The high proportion of isomer I (compound 4: $85 \%$ and compound 5: $70 \%$ ) as calculated from the integrals of the specific signals in the ${ }^{1} \mathrm{H}$ NMR spectra, is in agreement with an equatorial preference of the Me and $\mathrm{Ph}$ groups $\left(\Delta G_{\mathrm{Me}}^{\circ}=0.80-0.89\right.$ and $\left.\Delta G_{\mathrm{Ph}}^{\circ}=1.03 \mathrm{kcal} \mathrm{mol}^{-1}\right)^{1}$ located at position 5 of the 1,3-dioxane ring. However, the higher proportion of diastereoisomer III in the synthesis of compound $\mathbf{5}$ than in the case of compound $\mathbf{4}$ does not accord with the reported $A$-values of the two substituents ( $\mathrm{Me}$ and $\mathrm{Ph}$ ).

The axial or equatorial position of the substituents at

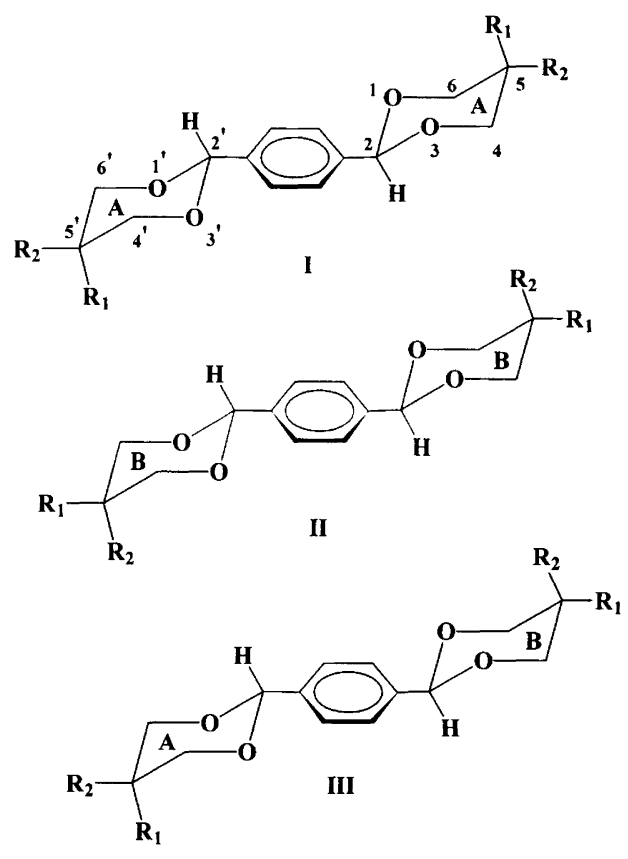

Scheme 3.

position $5\left(5^{\prime}\right)$ was deduced from the values of the coupling constants of the proton in position $5\left(5^{\prime}\right)$. If this proton were to exhibit an equatorial orientation it would show a small coupling with the vicinal equatorial or axial protons $\left(J_{\text {eq-ax }}\right.$ and $\left.J_{\text {eq-eq }}\right)$. If axial, however, its coupling constants with the vicinal axial proton would show high values $\left(J_{\mathrm{ax}-\mathrm{ax}}\right) .{ }^{1}$ The main isomer, $\mathbf{I}$, of compounds $\mathbf{4}$ and 5 was obtained as a pure product by several crystallisations from ethanol. The NMR spectra of this isomer showed one set of signals for the protons and the carbon atoms of the two heterocycles. The pattern of the ${ }^{1} \mathrm{H}$ NMR spectrum is characteristic of an anancomeric 1,3-dioxane ring bearing an equatorial substituent in position 5 of the heterocycle [e.g., the spectrum of compound 4 exhibits a doublet of doublets $(\delta 3.89$, $J_{4\left(4^{\prime}\right), 6\left(6^{\prime}\right) \text { eq- }-4\left(4^{\prime}\right) 6\left(6^{\prime}\right) \text { ax }}=11.3$ and $\left.J_{4\left(4^{\prime}\right), 6\left(6^{\prime}\right) \text { eq- }-5\left(5^{\prime}\right) \text { ax }}=4.6 \mathrm{~Hz}\right)$ for the equatorial protons and a triplet (overlapped doublet of doublets, $\delta 3.08, J_{4\left(4^{\prime}\right), 6\left(6^{\prime}\right) \text { ax }-5\left(5^{\prime}\right) \text { ax }}=11.3 \mathrm{~Hz}$ ) for the axial protons in positions $4\left(4^{\prime}\right)$ and $6\left(6^{\prime}\right)$ ].

The structure of the minor isomer was deduced from particular characteristics in the ${ }^{1} \mathrm{H}$ NMR spectrum of the mixture of isomers. Thus, after removal of the signals 
belonging to the main isomer, two other sets of signals with similar intensities were observed. These signals belong to diastereoisomer III, which shows two different 1,3-dioxane rings, one of which exhibits an equatorial methyl group in position 5 while the other ring has an axial methyl substituent. The protons in positions 2 and $2^{\prime}$ show two singlets $\left(\delta 5.30, \delta^{\prime} 5.32\right)$ and for the methyl groups in positions 5 and $5^{\prime}$ two doublets $\left[\delta\left(\mathrm{CH}_{3}\right)_{\mathrm{ax}} 1.18\right.$ and $\delta\left(\mathrm{CH}_{3}\right)_{\text {eq }}$ 0.22] were recorded. For the aromatic protons, instead of the singlet recorded in the case of compounds 1-3 and of diastereoisomer I of compounds 4 and 5 , the characteristic AB system for 1,4-disubstituted benzenes with different groups $\left(\delta_{\mathrm{A}} 7.60, \delta_{\mathrm{B}} 7.75\right.$ and $J=$ $8.1 \mathrm{~Hz}$ ) was observed.

The insignificant difference in the conformational free enthalpies ( $A$-values) between the methyl and the ethyl groups located in the aliphatic part of the 1,3-dioxane ring $\left(\Delta G_{\mathrm{Me}}^{\circ}=0.80-0.89\right.$ and $\Delta G_{\mathrm{Et}}^{\circ}=$ $\left.0.75-0.81 \mathrm{kcal} \mathrm{mol}^{-1}\right)^{1}$ may be the cause of the presence of three possible diastereoisomers during the synthesis of 6 (Scheme 3). The ratio between these isomers is in accordance with statistical rules (I: II : III $=1: 1: 2$ ). The ${ }^{1} \mathrm{H}$ NMR spectrum (Fig. 3, Table 2) of this compound, a mixture of all diastereoisomers, showed for the protons in positions 2 and $2^{\prime}$ four singlets with fairly similar intensities. The protons in position 2 and $2^{\prime}$ are equivalent in diastereoisomers I and II but are different in diastereoisomer III. Similar intensities for the four signals can only be obtained if diastereoisomer III has twice the population of diastereoisomers I and II. Diastereoisomers I and II have similar populations in agreement with their similar conformational energies. The signals of these
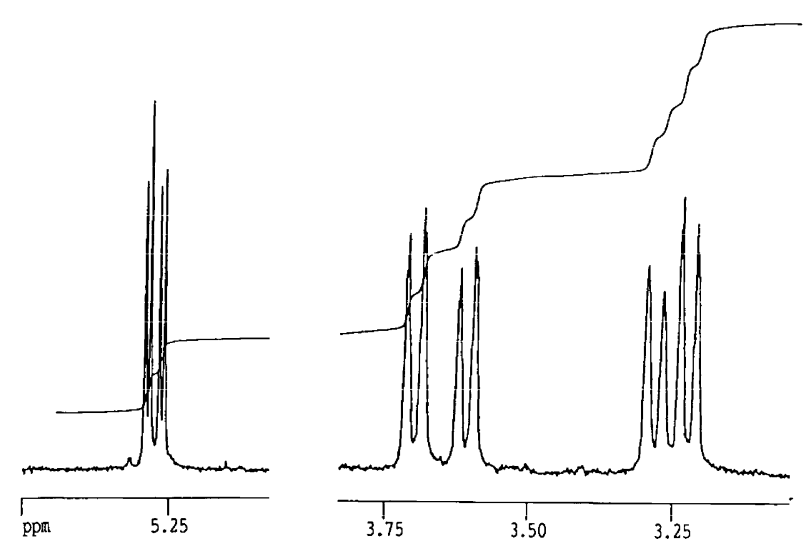

Fig. 3. ${ }^{1} \mathrm{H}$ NMR spectrum (fragment) of the mixture of diastereoisomers of compound $\mathbf{6}$. three diastereoisomers are overlapped and their complete NMR characterisation was not possible. However, two important groups of signals of similar intensities could be observed. One set of signals belongs to the rings (denoted A) bearing equatorial ethyl groups, the two heterocycles of diastereomer I and one of the 1,3-dioxane rings of diastereoisomer III and the other set of signals is due to the protons of the rings (denoted B) bearing axial ethyl groups (the two rings of diastereoisomer II and one 1,3-dioxane ring of diastereoisomer III). The assignment of the signals belonging to the substituents at position $5\left(5^{\prime}\right)$ took into account the significantly higher deshielding of the protons in the axial groups [for the ethyl group: $\Delta \delta\left(\mathrm{CH}_{2}\right)_{\mathrm{ax}-\mathrm{eq}} 1.01$ and $\Delta \delta\left(\mathrm{CH}_{3}\right)_{\mathrm{ax}-\mathrm{eq}}$ 0.23 ; for the methyl groups: $\Delta \delta_{\text {ax-eq }} 0.89$, Table 3]. The assignment of the signals due to the protons in positions $4\left(4^{\prime}\right)$ and $6\left(6^{\prime}\right)$ for the two types of ring was made using NOE experiments. Irradiation of the singlet due to the protons of the axial methyl group $(\delta 1.17)$ showed in the NOE difference spectrum a large influence on the doublet at $\delta 3.61$ (equatorial protons of rings $\mathrm{A}$ ) while irradiation of the singlet due to the protons of the equatorial methyl groups $(\delta 0.28)$ showed, in the NOE difference spectrum an influence on the doublets belonging to the protons of ring $\mathrm{B}\left(\delta_{\mathrm{eq}} 3.70\right.$ and $\left.\delta_{\mathrm{ax}} 3.22\right)$. The higher influence of the NOE effect on the more shielded doublet confirmed the axial position of the protons associated with this signal. The equatorial position of the protons giving the more deshielded doublet (rings B) was confirmed by irradiation of the quartet due to the methylene protons $(\delta 1.72)$ of the axial ethyl group (rings B). When the NOE difference spectrum was recorded a large enhancement was observed only on this doublet $(\delta 3.70)$. The 2D-homonuclear COSY spectrum revealed long range couplings $\left({ }^{4} \mathrm{~J} \approx 2.0 \mathrm{~Hz}\right)$ between the protons of the axial methylene or the methyl groups in position $5\left(5^{\prime}\right)$ and the axial protons of the heterocycles [positions $4\left(4^{\prime}\right)$ and $\left.6\left(6^{\prime}\right)\right]$.

\section{Conclusions}

The present study on the stereochemistry of 1,3-dioxane derivatives of 1,4-benzenedicarbaldehyde has shown the anancomeric structure of all the investigated compounds (1-6) and the preference for equatorial disposition of the aromatic group of both heterocycles. The diastereoselectivity of the acetalization reaction for diastereoisomer $I$ in compounds 4 and 5 has been explained by the equatorial preference of the substituents located in posi-

Table 3. ${ }^{1} \mathrm{H}$ NMR data $(\delta)$ for the substituents located at position $5\left(5^{\prime}\right)$ of the 1,3-dioxane rings in compound 6.

\begin{tabular}{|c|c|c|c|c|c|c|}
\hline \multirow[b]{2}{*}{ Ring } & \multicolumn{4}{|l|}{ Ethyl } & \multicolumn{2}{|l|}{ Methyl } \\
\hline & $-\mathrm{CH}_{2}(\mathrm{eq})$ & $-\mathrm{CH}_{2}(\mathrm{ax})$ & $-\mathrm{CH}_{3}(\mathrm{eq})$ & $-\mathrm{CH}_{3}(\mathrm{ax})$ & eq & $a x$ \\
\hline$A$ & 0.71 & - & $\begin{array}{l}0.529 \\
0.532\end{array}$ & - & - & 1.17 \\
\hline B & - & 1.72 & - & $0.757,0.762$ & $0.276,0.280$ & - \\
\hline
\end{tabular}


tion $5\left(5^{\prime}\right)$ of the heterocycles. The preference for diastereoisomer III during the synthesis of compound $\mathbf{6}$ is considered to be determined by statistical rules. The equatorial and axial dispositions of the substituents located in position $5\left(5^{\prime}\right)$ of the 1,3-dioxane ring have been deduced from the specific values of the coupling constants and chemical shifts.

\section{Experimental}

General. NMR: Bruker AM $400 \quad(400 \mathrm{MHz}$ and $100.6 \mathrm{MHz}$ for ${ }^{1} \mathrm{H}$ and ${ }^{13} \mathrm{C}$, respectively). and Varian Gemini $300\left(300 \mathrm{MHz}\right.$ and $75 \mathrm{MHz}$ for ${ }^{1} \mathrm{H}$ and ${ }^{13} \mathrm{C}$ ). $\mathrm{Me}_{4} \mathrm{Si}$ was not added and the chemical shifts are relative to the solvent line of $\mathrm{C}_{6} \mathrm{D}_{6}$. Melting points were determined with an Electrothermal apparatus and are uncorrected.

$X$-Ray crystallographic study. Compound 2. $\mathrm{C}_{26} \mathrm{H}_{34} \mathrm{O}_{12}$, monoclinic, $\quad P 21 / c, \quad a=12.875(2), \quad b=9.547(4)$, $c=12.027(1) \AA, \quad \beta=115.29(1)^{\circ}, \quad V=1336.7(5) \AA^{3}$, $Z=2, \quad D_{\mathrm{x}}=1.338 \mathrm{Mg} \mathrm{m}^{3}, \quad \lambda(\mathrm{MoK} \alpha)=0.70926 \AA, \mu=$ $0.994 \mathrm{~cm}^{-1}, F(000)=572, T=294 \mathrm{~K}$. final $R=0.042$ for 1379 observations. The sample $(0.40 \times 0.40 \times 0.55 \mathrm{~mm})$ was studied on an automatic CAD4 Enraf-Nonius diffractometer with graphite monochromated Mo K $\alpha$ radiation. The cell parameters were obtained by fitting a set of 25 high-theta reflections. The data collection $\left[2 \theta_{\max }=50^{\circ}, \quad\right.$ scan $\omega / 2 \theta=1, \quad t_{\max }=60 \mathrm{~s}$, range $h \mathrm{kl}$ : $h-15.15, k 0.11, l 0.14$, intensity controls without appreciable decay $(0.3 \%)$ ] gave 2632 reflections from which 1379 were independent $(R=0.014)$ with $I>3 \sigma(I)$.

After Lorenz and polarisation corrections the structure was solved by direct methods with the program SHELX-86. ${ }^{13}$ The structure determination revealed all the non-hydrogen atoms of the compound. After isotropic $(R=0.010)$, then anisotropic refinement $(R=$ 0.083 ), all the hydrogen atoms were found with a Fourier difference (between 0.55 and 0.21 e $\AA^{-3}$ ). The complete structure was refined by the full-matrix least-square techniques \{use of $F$ magnitude; $x, y, z, \beta_{i j}$ for $\mathrm{C}$ and $\mathrm{O}$ atoms and $x, y, z$ for $\mathrm{H}$ atoms; 224 variables and 1379 observations; $\left.\quad w=1 / \sigma\left(F_{\mathrm{o}}\right)^{2}=\left[\sigma^{2}(I)+\left(0.04 F_{\mathrm{o}}{ }^{2}\right)^{2}\right]^{-1 / 2}\right\}$ leading to $R=0.044, R_{\mathrm{w}}=0.042$ and $S_{\mathrm{w}}=0.79$ (residual

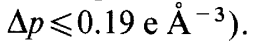

Atomic scattering factors were taken from International Tables for X-Ray Crystallography. ${ }^{14}$ The calculations in connection with the structure determination were performed on a Hewlett Packard $9000 \times 710$ while refinement and ORTEP calculations ${ }^{15,16}$ were performed on a Digital MicroVAX 3100 computer with the MOLEN package (Enraf-Nonius, 1990).

Compounds 1-6. General Procedure. $0.2 \mathrm{~mol}$ of the 1,3-diol and $0.1 \mathrm{~mol}$ of 1,4-benzenedicarbaldehyde together with a catalytic amount of $p$-toluenesulfonic acid $(0.1 \mathrm{~g})$ were dissolved in $200 \mathrm{ml}$ of benzene. The mixture was refluxed and the water formed was removed using a Dean-Stark trap. When $80 \%$ of the theoretical amount of water had been formed, the catalyst was neutralised with $\mathrm{CH}_{3} \mathrm{COONa}$ powder in excess $(0.2 \mathrm{~g})$ with stirring over $0.5 \mathrm{~h}$. The reaction mixture was washed twice with $100 \mathrm{ml}$ water. The organic layer was dried with $\mathrm{Na}_{2} \mathrm{SO}_{4}$, the benzene was removed and the 1,3-dioxane derivatives purified by crystallisation from ethanol.

1,4-Bis (1,3-dioxan-2-yl) benzene 1. Solid, white crystals, m.p. $156-157^{\circ} \mathrm{C}$. Yield $60 \%$. Found: C 66.83 ; H 7.02 . Calc. for $\mathrm{C}_{14} \mathrm{H}_{18} \mathrm{O}_{4}$ : C 67.18; $\mathrm{H}$ 7.25. ${ }^{1} \mathrm{H}$ NMR $\left(\mathrm{C}_{6} \mathrm{D}_{6}\right)$ : $\delta 0.64\left[2 \mathrm{H}, \mathrm{dtt}, J=13.3, J^{\prime}=2.5, J^{\prime \prime}=1.3 \mathrm{~Hz}, 5\left(5^{\prime}\right)-\mathrm{H}_{\mathrm{eq}}\right]$, $1.85\left[2 \mathrm{H}, \mathrm{dtt}, J=13.3, J^{\prime}=12.3, J^{\prime \prime}=4.9 \mathrm{~Hz}, 5\left(5^{\prime}\right)-\mathrm{H}_{\mathrm{ax}}\right]$, $3.43\left[4 \mathrm{H}\right.$, ddd, $J=11.8, J^{\prime}=12.3, J^{\prime \prime}=2.5 \mathrm{~Hz}, 4\left(4^{\prime}\right)-\mathrm{H}_{\mathrm{ax}}$, $\left.6\left(6^{\prime}\right)-\mathrm{H}_{\mathrm{ax}}\right], 3.87\left[4 \mathrm{H}\right.$, ddd, $J=11.8, J^{\prime}=4.9, J^{\prime \prime}=1.3 \mathrm{~Hz}$, $\left.4\left(4^{\prime}\right)-\mathrm{H}_{\mathrm{eq}}, 6\left(6^{\prime}\right)-\mathrm{H}_{\mathrm{eq}}\right], 5.30\left[2 \mathrm{H}, \mathrm{s}, 2\left(2^{\prime}\right)-\mathrm{H}_{\mathrm{ax}}\right], 7.73(4 \mathrm{H}$, $\mathrm{s}$, aromatic protons). ${ }^{13} \mathrm{C} \mathrm{NMR}\left(\mathrm{C}_{6} \mathrm{D}_{6}\right): \delta 26.01\left(\mathrm{C}^{5,5^{\prime}}\right)$, $64.08\left(\mathrm{C}^{4,4^{\prime}, 6,6^{\prime}}\right), 101.57\left(\mathrm{C}^{2,2^{\prime}}\right), 126.39$ (tertiary aromatic carbon atoms), 140.12 (quaternary aromatic carbon atoms).

Tetraethyl-2,2'-( 1,4-phenylene) bis( 1,3-dioxane)-5,5,5',5'tetracarboxylate 2. Solid, white crystals, m.p. 110-111 C. Yield 66\%. Found: C 58.27; $\mathrm{H}$ 6.48. Calc. for $\mathrm{C}_{26} \mathrm{H}_{34} \mathrm{O}_{12}$ : C 57.99; H 6.36. ${ }^{1} \mathrm{H}$ NMR $\left(\mathrm{C}_{6} \mathrm{D}_{6}\right): \delta 0.79[6 \mathrm{H}, \mathrm{t}, J=$ $\left.7.1 \mathrm{~Hz}, 5\left(5^{\prime}\right)-\mathrm{COOCH}_{2} \mathrm{CH}_{3}(\mathrm{eq})\right], 0.89[6 \mathrm{H}, \mathrm{t}, J=7.1 \mathrm{~Hz}$, $5\left(5^{\prime}\right)-\mathrm{COOCH}_{2} \mathrm{CH}_{3}(\mathrm{ax})$ ], 3.77 [ $4 \mathrm{H}, \mathrm{q}, J=7.1 \mathrm{~Hz}, 5\left(5^{\prime}\right)-$ $\left.\mathrm{COOCH}_{2} \mathrm{CH}_{3}(\mathrm{eq})\right], 3.95\left[4 \mathrm{H}, \mathrm{d}, J=10.9 \mathrm{~Hz}, 4\left(4^{\prime}\right)-\mathrm{H}_{\mathrm{ax}}\right.$, $\left.6\left(6^{\prime}\right)-\mathrm{H}_{\mathrm{ax}}\right], \quad 4.01 \quad\left[4 \mathrm{H}, \quad \mathrm{q}, \quad J=7.1 \mathrm{~Hz}, \quad 5\left(5^{\prime}\right)-\right.$ $\left.\mathrm{COOCH}_{2} \mathrm{CH}_{3}(\mathrm{ax})\right], 5.04\left[4 \mathrm{H}, \mathrm{d}, J=10.9 \mathrm{~Hz}, 4\left(4^{\prime}\right)-\mathrm{H}_{\mathrm{eq}}\right.$, $\left.6\left(6^{\prime}\right)-\mathrm{H}_{\mathrm{eq}}\right], 5.18\left[2 \mathrm{H}, \mathrm{s}, 2\left(2^{\prime}\right)-\mathrm{H}_{\mathrm{ax}}\right], 7.58(4 \mathrm{H}, \mathrm{s}$, aromatic protons). ${ }^{13} \mathrm{C} \quad \mathrm{NMR} \quad\left(\mathrm{C}_{6} \mathrm{D}_{6}\right): \quad \delta \quad 13.74 \quad\left[5\left(5^{\prime}\right)-\right.$ $\left.\mathrm{COOCH}_{2} \mathrm{CH}_{3}(\mathrm{eq})\right], \quad 13.91 \quad\left[5\left(5^{\prime}\right)-\mathrm{COOCH}_{2} \mathrm{CH}_{3}(\mathrm{ax})\right]$, $53.58\left(\mathrm{C}^{5,5^{\prime}}\right), 61.47 \quad\left[5\left(5^{\prime}\right)-\mathrm{COOCH}_{2} \mathrm{CH}_{3}(\mathrm{eq})\right], 61.59$ $\left[5\left(5^{\prime}\right)-\mathrm{COOCH}_{2} \mathrm{CH}_{3}(\mathrm{eq})\right], \quad 69.72\left\{\mathrm{C}^{4,4^{\prime}, 6,6^{\prime}}\right), \quad 101.44$ $\left(\mathrm{C}^{2,2^{\prime}}\right), 137.40$ (tertiary aromatic carbon atoms), 138.95 (quaternary aromatic carbon atoms).

1,4-Bis (5,5-dimethyl-1,3-dioxan-2-yl)-benzene 3. Solid, white crystals, m.p. $203-204{ }^{\circ} \mathrm{C}$. Yield $63 \%$. Found: C 70.80; $\mathrm{H}$ 8.71. Calc. for $\mathrm{C}_{18} \mathrm{H}_{26} \mathrm{O}_{4}$ : C 70.56; $\mathrm{H}$ 8.55. ${ }^{1} \mathrm{H}$ NMR $\left(\mathrm{C}_{6} \mathrm{D}_{6}\right): \delta 0.33\left[6 \mathrm{H}, \mathrm{s}, 5\left(5^{\prime}\right)-\mathrm{CH}_{3}(\mathrm{eq})\right], 1.18[6 \mathrm{H}$, s, 5( $\left.\left.5^{\prime}\right)-\mathrm{CH}_{3}(\mathrm{eq})\right], 3.25\left[4 \mathrm{H}, \mathrm{d}, J=10.8 \mathrm{~Hz}, 4\left(4^{\prime}\right)-\mathrm{H}_{\mathrm{ax}}\right.$, $6\left(6^{\prime}\right)-\mathrm{H}_{\mathrm{ax}}$ ], $3.52\left[4 \mathrm{H}, \mathrm{d}, J=10.8 \mathrm{~Hz}, 4\left(4^{\prime}\right)-\mathrm{H}_{\mathrm{eq}}, 6\left(6^{\prime}\right)-\right.$ $\left.\mathrm{H}_{\mathrm{eq}}\right], 5.25\left[2 \mathrm{H}, \mathrm{s}, 2\left(2^{\prime}\right)-\mathrm{H}_{\mathrm{ax}}\right], 7.77(4 \mathrm{H}, \mathrm{s}$, aromatic protons). ${ }^{13} \mathrm{C} \mathrm{NMR}\left(\mathrm{C}_{6} \mathrm{D}_{6}\right): \delta 21.69$ [5,5'- $\left.\mathrm{CH}_{3}(\mathrm{eq})\right]$, $23.16\left[5,5^{\prime}-\mathrm{CH}_{3}(\mathrm{ax})\right], \quad 30.04\left(\mathrm{C}^{5,5^{\prime}}\right), 77.46\left(\mathrm{C}^{4,4^{\prime}, 6,6^{\prime}}\right)$, $101.62\left(\mathrm{C}^{2,2^{\prime}}\right), 126.52$ (tertiary aromatic carbon atoms), 139.93 (quaternary aromatic carbon atoms).

1,4-Bis( 5-methyl-1,3-dioxan-2-yl) benzene 4 (diastereoisomer I). Solid, white crystals, m.p. $169-170^{\circ} \mathrm{C}$. Yield $75 \%$ for the mixture of diastereoisomers and $20 \%$ for the separated diastereoisomer I. Found: $\mathrm{C}$ 68.78; $\mathrm{H}$ 8.12. Calc. for $\mathrm{C}_{16} \mathrm{H}_{22} \mathrm{O}_{4}$ : C 69.04; $\mathrm{H}$ 7.97. ${ }^{1} \mathrm{H}$ NMR $\left(\mathrm{C}_{6} \mathrm{D}_{6}\right)$ : $\delta 0.21\left[6 \mathrm{H}, \mathrm{d}, J=6.7 \mathrm{~Hz}, 5\left(5^{\prime}\right)-\mathrm{CH}_{3}(\mathrm{eq})\right], 1.93[2 \mathrm{H}, \mathrm{m}$ (overlapped peaks), 5( $\left.\left.5^{\prime}\right)-\mathrm{H}_{\mathrm{ax}}\right], 3.08[4 \mathrm{H}, \mathrm{t}$ (overlapped dd $\left.), J=J^{\prime}=11.3 \mathrm{~Hz}, 4\left(4^{\prime}\right)-\mathrm{H}_{\mathrm{ax}}, 6\left(6^{\prime}\right)-\mathrm{H}_{\mathrm{ax}}\right], 3.89[4 \mathrm{H}$, $\left.\mathrm{dd}, J=11.3, J^{\prime}=4.6 \mathrm{~Hz}, 4\left(4^{\prime}\right)-\mathrm{H}_{\text {eq }}, 6\left(6^{\prime}\right)-\mathrm{H}_{\text {eq }}\right], 5.27[2 \mathrm{H}$, 
s, $\left.2\left(2^{\prime}\right)-\mathrm{H}_{\mathrm{ax}}\right], 7.76\left(4 \mathrm{H}\right.$, s, aromatic protons). ${ }^{13} \mathrm{C}$ NMR $\left(\mathrm{C}_{6} \mathrm{D}_{6}\right): \delta 11.96\left[5,5^{\prime}-\mathrm{CH}_{3}(\mathrm{eq})\right], 29.40\left(\mathrm{C}^{5,5^{\prime}}\right), 73.46$ $\left(\mathrm{C}^{4,4^{\prime}, 6,6^{\prime}}\right), \quad 101.24\left(\mathrm{C}^{2,2^{\prime}}\right), 137.39$ (tertiary aromatic carbon atoms), 139.73 (quaternary aromatic carbon atoms).

1,4-Bis (5-phenyl-1,3-dioxan-2-yl) benzene 5 (diastereoisomer I). Solid, white crystals, m.p. $216-217^{\circ} \mathrm{C}$. Yield $55 \%$ for the mixture of diastereoisomers and $23 \%$ for the separared diastereoisomer I. Found: C 77.83; H 6.77. Calc. for $\mathrm{C}_{26} \mathrm{H}_{26} \mathrm{O}_{4}$ : C 77.59; $\mathrm{H}$ 6.51. ${ }^{1} \mathrm{H}$ NMR $\left(\mathrm{C}_{6} \mathrm{D}_{6}\right)$ : $\delta 3.16\left[2 \mathrm{H}, \mathrm{tt}, J=11.0, J^{\prime}=4.6 \mathrm{~Hz}, 5\left(5^{\prime}\right)-\mathrm{H}_{\mathrm{ax}}\right], 3.68[4 \mathrm{H}$, $\mathrm{t}$ (overlapped dd), $J=J^{\prime}=10.8 \mathrm{~Hz}, 4\left(4^{\prime}\right)-\mathrm{H}_{\mathrm{ax}}, 6\left(6^{\prime}\right)-\mathrm{H}_{\mathrm{ax}}$, $4.15\left[4 \mathrm{H}, \mathrm{dd}, J=10.8, J^{\prime}=4.6 \mathrm{~Hz}, 4\left(4^{\prime}\right)-\mathrm{H}_{\mathrm{eq}}, 6\left(6^{\prime}\right)-\mathrm{H}_{\mathrm{eq}}\right.$ ], $5.41\left[2 \mathrm{H}, \mathrm{s}, 2\left(2^{\prime}\right)-\mathrm{H}_{\mathrm{ax}}\right], 7.86(4 \mathrm{H}, \mathrm{s}$, aromatic protons). ${ }^{13} \mathrm{C}$ NMR $\left(\mathrm{C}_{6} \mathrm{D}_{6}\right): \delta 41.47\left(\mathrm{C}^{5,5^{\prime}}\right), 72.30\left(\mathrm{C}^{4,4^{\prime}, 6,6^{\prime}}\right)$, $101.34\left(\mathrm{C}^{2,2^{\prime}}\right), 126.58,127.92,128.33,128.89$ (tertiary aromatic carbon atoms), 132.90, 140.33 (quaternary aromatic carbon atoms).

1,4-Bis (5-ethyl-5-methyl-1,3-dioxan-2-yl) benzene 6 (mixture of diastereomers). Solid, white crystals, m.p. $203-204^{\circ} \mathrm{C}$. Yield $78 \%$. Found: C 72.07; H 9.22. Calc. for $\mathrm{C}_{20} \mathrm{H}_{30} \mathrm{O}_{4}$ : C 71.82; $\mathrm{H}$ 9.04. ${ }^{1} \mathrm{H}$ NMR $\left(\mathrm{C}_{6} \mathrm{D}_{6}\right)$ : $\delta 0.276,0.280\left[3 \mathrm{H}, \mathrm{s}, 5\left(5^{\prime}\right)-\mathrm{CH}_{3}(\mathrm{eq})\right], 0.529,0.532[3 \mathrm{H}$, $\left.\mathrm{t}, J=7.7 \mathrm{~Hz}, 5\left(5^{\prime}\right)-\mathrm{CH}_{2} \mathrm{CH}_{3}(\mathrm{eq})\right], 0.71[2 \mathrm{H}, \mathrm{q}, J=$ $\left.7.7 \mathrm{~Hz}, 5\left(5^{\prime}\right)-\mathrm{CH}_{2} \mathrm{CH}_{3}(\mathrm{eq})\right], 0.757,0.762[3 \mathrm{H}, \mathrm{t}, J=$ $\left.7.7 \mathrm{~Hz}, 5\left(5^{\prime}\right)-\mathrm{CH}_{2} \mathrm{CH}_{3}(\mathrm{ax})\right], 1.17\left[3 \mathrm{H}, \mathrm{s}, 5\left(5^{\prime}\right)-\mathrm{CH}_{3}(\mathrm{ax})\right]$, $1.72\left[2 \mathrm{H}, \mathrm{q}, J=7.5 \mathrm{~Hz}, 5\left(5^{\prime}\right)-\mathrm{CH}_{2} \mathrm{CH}_{3}(\mathrm{ax})\right], 3.22[2 \mathrm{H}$ (rings B), d, $\left.J=11.3 \mathrm{~Hz}, 4\left(4^{\prime}\right)-\mathrm{H}_{\mathrm{ax}}, 6\left(6^{\prime}\right)-\mathrm{H}_{\mathrm{ax}}\right], 3.28$ [2H (rings A), d, $J=11.3 \mathrm{~Hz}, 4\left(4^{\prime}\right)-\mathrm{H}_{\mathrm{ax}}, 6\left(6^{\prime}\right)-\mathrm{H}_{\mathrm{ax}}$ ], 3.61 [2H (rings A), d, $\left.J=11.3 \mathrm{~Hz}, 4\left(4^{\prime}\right)-\mathrm{H}_{\mathrm{eq}}, 6\left(6^{\prime}\right)-\mathrm{H}_{\mathrm{eq}}\right]$, 3.70 [2H (rings B), d, $J=11.3 \mathrm{~Hz}, 4\left(4^{\prime}\right)-\mathrm{H}_{\mathrm{eq}}, 6\left(6^{\prime}\right)-\mathrm{H}_{\mathrm{eq}}$ ], 5.259, $5.2685 .283,5.292\left[2 \mathrm{H}, \mathrm{s}, 2\left(2^{\prime}\right)-\mathrm{H}_{\mathrm{ax}}\right], 7.73,7.75$, 7.77(4 $\mathrm{H}$, aromatic protons) ${ }^{13} \mathrm{C}$ NMR $\left(\mathrm{C}_{6} \mathrm{D}_{6}\right): \delta 6.91$ [5(5')- $\left.\mathrm{CH}_{2} \mathrm{CH}_{3}(\mathrm{eq})\right], 8.04$ [5(5')- $\left.\mathrm{CH}_{2} \mathrm{CH}_{3}(\mathrm{ax})\right], \quad 18.08$ $\left[5\left(5^{\prime}\right)-\mathrm{CH}_{3}(\mathrm{eq})\right], 19.69\left[5\left(5^{\prime}\right)-\mathrm{CH}_{3}(\mathrm{ax})\right], 27.22\left[5\left(5^{\prime}\right)-\right.$
$\mathrm{CH}_{2} \mathrm{CH}_{3}$ (eq)], 28.90 [5(5')- $\left.\mathrm{CH}_{2} \mathrm{CH}_{3}(\mathrm{ax})\right], 32.61,32.63$ $\left(\mathrm{C}^{5,5^{\prime}}\right), 75.62,76.75\left(\mathrm{C}^{4,4^{\prime}, 6,6^{\prime}}\right), 101.73,101.93\left(\mathrm{C}^{2,2^{\prime}}\right)$, 137.50 (tertiary aromatic carbon atoms) $139.84,139.93$ (quaternary aromatic carbon atoms).

\section{References}

1. Anteunis, M. J. O., Tavernier, D. and Borremans, F. Heterocycles 4 (1976) 293.

2. Nader, F. W. and Eliel, E. L. J. Am. Chem. Soc. 92 (1970) 3050.

3. Bailey, W. F. and Eliel, E. L. J. Am. Chem. Soc. 96 (1974) 1798.

4. Bernaert, E., Anteunis, M. J. O. and Tavernier, D. Bull. Soc. Chim. Belg. 83 (1974) 357.

5. De Kok, A. J. and Romers, C. Recl. Trav. Chim. Pays-Bas 89 (1970) 313

6. Collins, P. M., Travis, A. S., Tsiquaye, K. N., Lindley, P. F. and Perratt, D. J. Chem. Soc, Perkin Trans. 1 (1974) 1895.

7. Nader, F. W. Tetrahedron Lett. 14 (1975) 1207.

8. Grosu, I., Mager, S., Plé, G., Plé, N., Toscano, A., Mesaros, E. and Martinez, R. Liebigs Annalen/Recueil (1997). In press.

9. Grosu, I., Mager, S., Mesaros, E. and Plé, G. Heterocycl. Commun. (1997). In press.

10. Grosu, I., Mager, S. and Plé, G. Tetrahedron 51 (1995) 2659.

11. Grosu, I., Mager, S., Plé, G., Martinez, R., Muntean, L. and Mesaros, E. Heterocycles 41 (1995) 2233.

12. Grosu, I., Mager, S., Plé, G., Muntean, L. and Schirger, I. Heterocycl. Commun. 2 (1996) 423.

13. Sheldrick, G. M. Crystallographic Computing 3: Data Collection, Structure Determination, Proteins and Databases, Clarendon Press, Oxford, 1985.

14. International Tables for X-Ray Crystallography, Kynoch Press, Birmingham 1974.

15. Johnson, C. K. Ortep. Report ORNL-3794. Oak Ridge National Laboratory Tennessee, USA 1965.

16. Fair, C. K. Molen. An Interative Intelligent System for Crystal Structure Analysis, Enraf-Nonius, Delft, The Netherlands 1990.

Received July 7, 1997. 